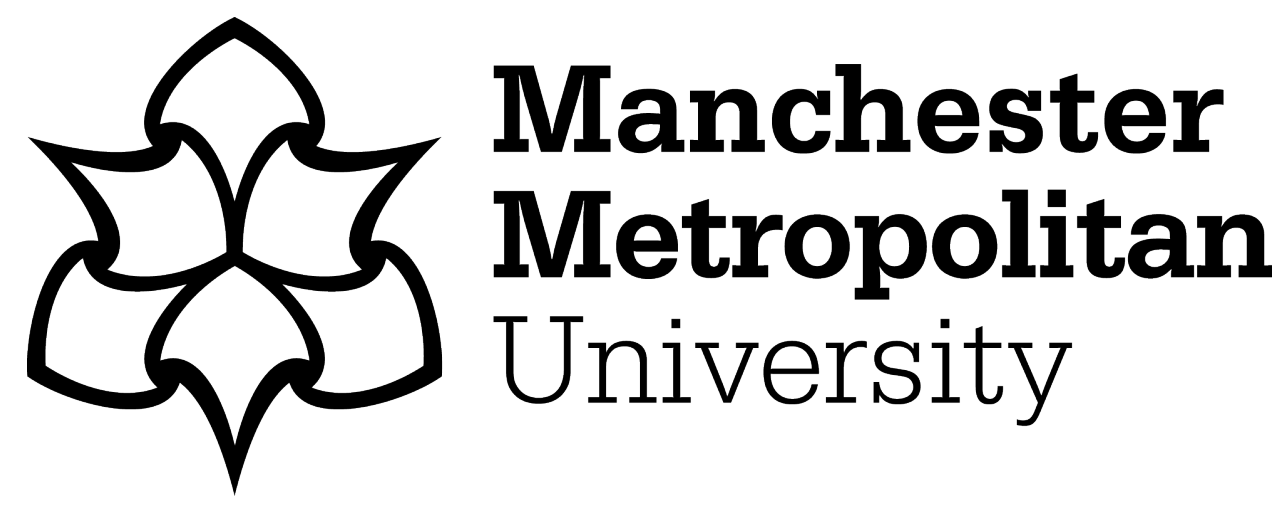

Legg, C and Giladi, P (2018) Metaphysics - Low in Price, High in Value: A Critique of Global Expressivism. Transactions of the Charles S. Peirce Society, 54 (1). pp. 64-83. ISSN 0009-1774

Downloaded from: https://e-space.mmu.ac.uk/621006/

Publisher: Indiana University Press

DOI: https://doi.org/10.2979/trancharpeirsoc.54.1.04

Please cite the published version 


\section{Metaphysics - Low in Price, High in Value: A Critique of Global Expressivism}

\section{Introduction ${ }^{1}$}

Neopragmatism is currently a burgeoning area of philosophical research, and Huw Price is positioned as a key heir of its originary figure Richard Rorty. ${ }^{2}$ In the late 1960 s and early ' $70 \mathrm{~s}$, Rorty famously burst onto an Anglo-American philosophical scene largely dominated by stillpositivistic analytic philosophy ${ }^{3}$ and initiated a great revival for pragmatism. This intervention provoked a significant counter-reaction. ${ }^{4}$ Rorty's ideas were widely viewed as blithely disregarding important issues such as whether reality exists, and if so what is its nature, and erasing the possibility of principled distinctions between ground-breaking scientific inquiry, great works of Western Philosophy, and any other "kind of writing" (Rorty 1978, pp. 141-160). That Rorty not only engaged philosophically with 'Continental' figures such as Nietzsche, Heidegger and Derrida, but arranged them alongside core analytic authors such as Quine in creative thematic comparisons, only made the counter-reaction more intense.

By contrast, Price claims to situate neo-pragmatist insights within a more sober and respectable naturalism. He has enriched philosophical debate with a distinction between object naturalism, which pertains to the world at large, and subject naturalism, which pertains solely to us humans. But what Price means by naturalism turns out to be in effect largely the exhortation: Do not engage in any metaphysics! $!^{5}$ Our paper is directed against this aspect of Price's thought. First, we will suggest that understanding naturalism as defined against metaphysics is misguided if one considers the goals of the 'natural' sciences which allegedly inspire the view. (We shall argue that metaphysics should be understood as a sufficiently general inquiry into the nature and structure of reality.) Secondly, we will argue that Price himself is philosophically inconsistent - his recent work is replete with metaphysical

\footnotetext{
${ }^{1}$ Thanks are due to Thomas Dabay and Joshua Black for philosophical interactions which significantly improved this paper.

${ }^{2}$ For example, Robert Brandom writes, "Huw Price is one of the boldest and most original voices of pragmatism in the generation after Richard Rorty and Hilary Putnam" (Brandom, in Price 2013, p. 85).

${ }^{3}$ Analytic philosophy at the time arguably thought of itself as post-positivist, due for instance to Quine's critique of Carnap. We disagree with this self-assessment. We do not have space here to argue the matter, but see (Redding 2010, p. 20).

${ }^{4}$ For an overview, see (Misak 2013, pp. 225-228)

${ }^{5}$ Here we differ from Horwich's 2013 critique of Price as allegedly trying to "derive metaphysical theories from linguistic premises" (Horwich, in Price 2013, p. 114). We feel that this critique does not do sufficient justice to Price's overarching goal of quietism, adumbrated in particular detail in (Macarthur and Price 2007).
} 
assumptions. We will identify and discuss the two we see as most substantial: dualism and nominalism.

We begin by outlining in sections 2 and 3 key features of Price's naturalism and his arguments for it. In section 4 we argue that Price is committed to dualism on a number of levels, which problematically cements an in-principle lack of explanation across these dualistic divides, thereby compromising his naturalism. In section 5 we argue that Price is committed to nominalism concerning the meaning of general terms through his metaphysical quietism and functional pluralism, which undermines the objective purport of the overall view he seeks to establish (namely global expressivism). We believe these discussions are important to have as the question of whether it is acceptable for philosophers to value the pursuit of metaphysics and if so, why and how it should be pursued - has significant implications for the heart and soul of pragmatism as it continues to develop its newly-revived self. We conclude with some thoughts on these broader metaphilosophical implications.

\section{The Road to Global Expressivism}

Price follows Rorty, Brandom and many other neopragmatists ${ }^{6}$ in positioning pragmatism as a critique of representationalism: the idea that "the function of statements is to 'represent' worldly states of affairs, and...true statements succeed in doing so" (Price 2011, p. 4). In other words, sentences are made true by - and notions such as truth, and objectivity can be explained by - a so-called word-world relation. So for instance, "Snow is white" is made true by the existence of white snow, which in turn is claimed to explain why the sentence "Snow is white" is true.

Why would one deny that true sentences represent the world? Certain neopragmatists have influentially claimed that many statements endorsed by humans are made not because they correspond to worldly facts, but because they are useful. Therefore, any existing items posited to 'truth-make' those statements are a chimera that unhelpfully masks genuine sources of truth in human concerns and purposes. Thus, Rorty asks poignantly what entities might truth-make, "History is the story of class struggle" and, "Love is the only law" (Rorty 1982, p. 163), and notoriously, in a number of places recommends that philosophers cease talking about truth entirely. ${ }^{7}$

\footnotetext{
${ }^{6}$ See for instance, Michael Williams, "The heart of pragmatism is anti-representationalism" (Williams, in Price 2013, p. 129).

${ }^{7}$ This is at least some of what Rorty means by his concept of a post-Philosophical culture (Rorty 1982, p. xlii). See also: "[truth is] not the sort of thing one should expect to have an interesting philosophical theory about"
} 
Yet at the same time as Price rejects representationalism, and its interpretation of objectivity in an independent world, which is nonetheless somehow connected to our words, he is concerned to honour naturalism, which he describes as "an ontological doctrine...[that] all there $i$ is the world studied by science", and "an epistemological doctrine...[that] all genuine knowledge is scientific knowledge" (Price 2004, p. 73). Price urges that although naturalism is generally thought to require representationalism, his representation-free naturalism is superior. As noted, Price distinguishes object naturalism, which claims that the proper concern of philosophy is "with something in the natural world, or with nothing at all. For there simply is nothing else" from subject naturalism, which claims that philosophy "needs to begin with what science tells us about ourselves" (Price 2013, p. 5). Price argues that subject naturalism should 'come first' philosophically in an important sense, for object naturalism depends on "validation from a subject naturalism perspective". This simply means that if certain presuppositions of object naturalism are incompatible with "the recognition that we humans are natural creatures" (Price 2013, p. 6), then they should be rejected. As an example, Price proffers what he calls the Placement Problem. ${ }^{9}$

This problem proceeds as follows. As humans, we often seek to explain the world we experience. On Price's recommended subject naturalist approach, we should start this explanation with ourselves - this is the Priority Thesis (Price 2004, pp. 73-4). Adhering to this recommendation will lead us when developing our naturalism to examine in the first instance our "human linguistic usage" - what we say (Price 2004, p. 75). And when we do this, Price claims, we will notice a "lack of fit" between certain of our linguistic practices and natural science. At various times Price has suggested that the problematic practices include talk about: modality, meaning, universals, moral, epistemic and aesthetic norms, and intentionality. ${ }^{10}$

Take ethics for example. In ordinary language we make and endorse statements such as, "Stealing is wrong". This statement appears to attribute a property (wrongness) to an object (stealing). But does it? The Placement Problem problematizes where a property of wrongness

(Rorty 1982, p. xiii), "[and we ought to] substitute the idea of 'unforced agreement' for that of "objectivity"” (Rorty 1991, p. 36).

${ }^{8}$ One might wonder at this point what exactly is meant by 'natural', but Price doesn't tell us any more than that it is what is studied by natural science (Price 2011, p. 4). Issues abound here concerning exactly which sciences should be thought of as "natural" (psychology? economics? sociology?), and also whether Price is referring to facts recognised by current natural science, future natural science, or some kind of idealization of all possible scientific inquiry. These issues were well explored regarding physicalism almost 30 years ago in (Crane and Mellor 1990).

${ }^{9}$ Price's Placement Problem owes much to (Jackson 1998), where it is dubbed "The Location Problem", although Price endeavours to distinguish them (Price 2013, p. 27n).

${ }^{10}$ See (Price 1988, 1997a, 2004, 2010, 2011, and 2013). 
might 'fit' in the natural world described by science. How? Price skips lightly over this part of the argument, but it is as though he is thinking of reality like a giant container into which scientists 'place' blocks corresponding to scientific facts as they discover them. It is then envisaged that once science has finished its work, and described all the facts, the container is 'full' - there is no room to place any more blocks in it. ${ }^{11}$

Price also offers a somewhat different illustrative metaphor (2011 and 2013), inviting us to imagine the relationship between our linguistic practices and the world as a child's puzzle sticker book, where the right-hand side of each page holds a picture of a complex scene, and the left hand side a column of peel-off stickers. For each sticker, Price states, the child needs to find the corresponding object in the picture (Price 2013, p. 23). He suggests that we think of the right-hand side as the world, and the stickers as the set of sentences true of it. Within this model, issues of 'fit' (or placement) arise insofar as: "We seem to have...more stickers than places to put them." (Price 2013, p. 26). For, he claims, ordinary discourse is 'rich' and the world described by natural science is 'sparse' (Price 2011, p. 4).

Price also argues that a key presupposition of The Placement Problem is what he calls "the Semantic Ladder", which derives from representationalism. This is:

the assumption that the linguistic items in question 'stand for' or 'represent' something non-linguistic...This assumption grounds our shift in focus from the term ' $\mathrm{X}$ ' or concept X, to its assumed object, X (Price 2013, p. 9).

This assumption is required for the Placement Problem, for without it we cannot transition from merely studying human linguistic practices (such as ethics talk), to considering their implications for the world. So, one may evade the Problem by refusing to climb the Ladder.

One form of such philosophical evasion, Price explains, is expressivism, the view that although words have meanings, they do not necessarily represent something non-linguistic. Rather, we may use words as tools to achieve other purposes. So an expressivist would attempt to resolve the Placement Problem for ethics by deciding that our statement "Stealing is wrong", is used not for representing a moral fact, but for functions such as dissuading children from certain behaviours. Price turns to Blackburn's quasi-realism to explain why nevertheless moral statements have been thought truth-apt, and why we express them in declarative form - because they play a vital function in our daily lives, and thereby express something important about ourselves (Price 2013, pp. 29-31).

${ }^{11}$ See (Price 2004, pp. 74-75), (Macarthur and Price, 2007, pp. 93-94). 
However, crucially, Price then 'goes global' with his expressivism. He argues that all words are merely tools; none represent anything 'non-linguistic' - thereby tossing away the Semantic Ladder. He concludes that none of the content of our semantic predicates with representational purport (such as 'true' and 'represents') is actually semantic. Previously he has suggested that such terms are exhausted by merely syntactical roles - holding a minimalism (e.g. Price 1988). More recently he has urged that Brandom's normative pragmatics of assertion may usefully be imported wholesale into his theory (Price 2013, p. 31). His stated reason for the bold move of extending expressivism to all statements is that trying to draw a principled distinction between areas of discourse which do and do not represent (the so-called Bifurcation Thesis) seems excessively complicated:

A quasi-realist of a more conventional stripe, who does want to hold onto the Bifurcation Thesis, is committed to a kind of two-tier view of the landscape...In effect, he must think that there are both loose and strict answers to questions such as: What is [it] to be a belief, an assertion, a statement..." (Price 2013, p. 30).

The distinction also seems arbitrary and useless, Price suggests. Since we have managed to provide a full explanation of semantic predicates in the merely expressive case (entirely by reference to human natural functions), there seems little point in crafting a further account for purported descriptive cases - the success of local expressivism will render it "an idle cog". ${ }^{2}$

Price acknowledges that holding a global expressivism risks draining expressivism of its meaning, since 'expressing' is usually defined precisely in contrast to 'representing' - a charge mounted influentially in (Boghossian 1990). But Price claims immunity from the charge as he is providing a new ("use-explanatory") account of expressing that is not defined using traditional semantic notions, which are a framework that he simply rejects (Price 2013, pp. 1112). As an olive branch to the long history of philosophers' contrasting representing with nonrepresenting uses of language, he offers a new distinction, aiming to recapitulate as much of the contrast as possible within global expressivism, which he calls $e$-and i-representation.

E-representations are explicated as "environment-tracking" - they co-vary with some feature of the world claimed to be external. An example offered is the needle on a fuel gauge co-varying with fuel-level in the tank. By contrast, i-representations are defined in terms of the "internal functional role" of representation - "its position or role in some cognitive or inferential architecture" (Price 2013, p. 36). No example is given of this but perhaps the number 2 might serve, for its position in a structured network of mathematical concepts. Price claims

\footnotetext{
12 (Macarthur and Price 2007, pp. 104-109). See also (Price 2013, p. 30.)
} 
that the natural way to read this distinction is that i-representations are merely logically sophisticated versions of e-representations, understood within an overall representational framework. Within global expressivism, though, the distinction must be reconceived, and Price suggests (drawing on pragmatism) that the two systems serve different, complementary purposes. The purpose of i-representations is "in-game answerability" - matters such as logical consistency, relevance and other aspects of 'score-keeping in a language-game', and the purpose of e-representations is "environmental answerability" (Price 2013, p. 38). 'Environment' here refers to the world we have in view from the natural sciences, although we are not representing it in the traditional sense. How can we be answerable to the natural world if we don't represent it? We merely covary with it (Price 2013, p. 37). We may successfully make predictions about it, but our theories are thoroughly infused by the contingencies of our particular human purposes (for instance, a theory of causation would be inconceivable for creatures that were not agents in the world).

\section{Global Expressivism as Anti-Metaphysics}

At this point we reach the reasons for, and the nature of, Price's repudiation of metaphysics. Firstly, Price appears to assume, following Quine, that doing metaphysics is coextensive with 'having ontological commitments'. ${ }^{13}$ Secondly, he assumes that ontological commitments can be undertaken only by using language to represent facts in a supposedly external world. ${ }^{14}$ Given these two assumptions, the representationalist claim that there are "substantial word-world relations" (Price 2004, p. 78) seems to be all that could be meant by metaphysics. ${ }^{15}$ It then follows that to adopt an expressivist position regarding a given area of discourse is to abandon the possibility of that discourse having any ontological commitments, and thus any metaphysical import, and to adopt global expressivism is to abandon the possibility of any metaphysics whatsoever.

\footnotetext{
13 This apparent assumption is somewhat puzzling since in a rich discussion in (Price 1997b), Price criticises Quine for being too quick to allege that in significant philosophical debates of his day "the crucial issues are ontological" (as opposed to, for instance, functional), and also for alleging (against Carnap) that the existential quantifier is entirely univocal. And yet without such an assumption, Price's claim that his global expressivism consists in a repudiation of metaphysics simply does not follow. For instance, why cannot exploring the range of linguistic functions that human language makes possible itself constitute a metaphysical inquiry? (More on this later in the paper.)

14 This would be an interesting assumption to press on, and not without support from defenders of classical pragmatism who have recently begun deploring neopragmatism's extensive focus on language, arguing that it overrides one of pragmatism's key originating concepts: experience. See for instance (Koopman 2007), (Levine 2012).

${ }^{15}$ Price goes so far as to state, “... semantic notions such as reference and truth have become instruments in the investigative programme of modern metaphysics” (Price 2004, pp. 84-85).
}

Commented [A1]: Footnote 13 is all to answer the charge of REFEREE \#1 that we need to back up our claim that Price is Quinean here 
It is worth pausing here and noting a certain oddness about this view, particularly as a form of naturalism. Is Price claiming that there is no reality? An obvious quick rejoinder here might run: Is Price not doing metaphysics precisely in throwing away the Semantic Ladder? Is he not denying that all of our terms have reference? And is this not a metaphysical claim? This of course echoes a well-rehearsed objection to attempts to abolish metaphysics in 20th century philosophy by the logical positivists (Hempel 1976). Price is quite aware of the objection and has a well-prepared response. He claims that rather than denying metaphysical claims, he is avoiding them, and this is the more profound move (Macarthur and Price 2007, pp. 97-101). He also claims that his opponents, in pursuing metaphysical discussion with him, are begging the question against his view (Price 2003, pp. 180-183). Here Price echoes Rorty's famous philosophical move with respect to truth: he is not denying that there is truth so much trying to change the subject, exhorting philosophers to turn their energies to more worthwhile topics just as, both Rorty and Price suggest, atheists are trying to get us past even talking about God. ${ }^{16}$

Also, Price claims that pragmatists are metaphysical quietists but not quietists tout court ("philosophical quietists"). Such quietists take some issues very seriously, he claims, for instance anthropological ones (Macarthur and Price 2007, p. 101). Again, it is worth pausing and noting a certain prima facie oddness with Price's view. Is he arguing that anthropology has nothing to do with reality? But from his perspective the move to reject metaphysics yet uphold anthropology is legitimate, as it precisely quarantines philosophical inquiry within subject naturalism. We have now summarised key features of Price's distinctive neopragmatist interpretation of naturalism, and will begin our critique of his claim to repudiate metaphysics.

\section{Price's Dualism}

It should now be clear that Price's arguments rely on a number of robust two-way distinctions. In this section we shall briefly list these, then argue that the use to which Price puts them is sufficiently metaphysical to commit him to a de facto dualism. Then we shall suggest some ways in which we see dualism as a problematic metaphysics to have, if one is going to have a metaphysics.

First, and rather oddly, at one point Price explicitly claims to be a dualist, when he postulates his two kinds of representation: $i$ - and $e$-. He claims that these are so entirely different that his

\footnotetext{
${ }^{16}$ (Rorty 1982, p. xiv). See also (Price 2011, pp. 240-41): "Evolutionary biologists don't think that the species were created by God. Does this mean that they must use the term "God", in their theoretical voice, in order to deny that the species were created by God? Obviously not - they simply offer an account of the origin of the species in which the term "God" does not appear."
} 
global expressivism is not the nihilism many have imagined, but rather a form of dualism (Price 2013, p. 44). Although the remark appears somewhat jesting, he is quite correct to point out the profound distinctness of i- and e-representations. Why are they so distinct? While the former resembles a space of reasons, the latter seems more akin to direct causal interaction with objects in the world, and it has often been remarked that reasons are not causes. Yet how do these two very different kinds of representation combine into our relatively seamless human communication? Price gives no account of this. He merely claims that we should be content to have two quite different accounts of communication, and let them "live their separate lives" (Price 2013, p. 45). But aren't there some concepts that might be inferentially analysed and covaried with in practice, and in such cases, can we acknowledge and explain how we are talking about 'the same concept'? For example, many concepts in fundamental physics (which is of course highly naturalistically respectable) would seem to be precisely of this nature. How would Price analyse a phrase such as "two electrons"? He does not say.

The apparent dualism between i- and e-representation is puzzling enough, but Price goes on to coordinate these two kinds of representation with two kinds of world, also quite distinct: socalled $i$ - and $e$-worlds. The former, he claims, corresponds to "the totality of the facts" and the latter to "the natural environment" (Price 2013, p. 46). He suggests that there is in fact a range of different i-worlds corresponding to different discourses (what Wittgenstein called languagegames), and in a neat move he concludes that the e-world is the i-world of the scientific perspective. In moving from 'representation' to 'world' in such a fashion, isn't Price now himself climbing the dreaded Semantic Ladder? Of course, he denies that his postulation of these worlds constitutes an ontological rather than a functional claim (Price 2013, p. 55). Still, he seems to be here positing something beyond the e- and i-representations themselves, or why bother to define further terms?

Price's argument for his global expressivism also draws crucially on a number of further distinctions between 'representation-like entities' and 'world-like entities', which would appear to treat the two as effectively different 'realms'. Examples include contrasts between "linguistic data" and "the objects themselves" (Price 2013, p. 7), a "linguistic conception" of naturalism and a "material conception" (Price 2013, p. 8), and the "near end" and "far end" of "the semantic relation" (Price and Macarthur, 2007, p. 96). Given how Price construes the distinction between $\mathrm{i}$ - and e-representation as two different kinds of representation, and appears to posit something beyond the different kind of representations themselves, even though he would deny any ontologising move here, and given the strict distinctions Price maintains between the linguistic and the objectual, there is good reason to regard these three points as 
functioning metaphysically, in that they are concerned with a sufficiently general inquiry into the nature and structure of reality. To sum up, then, we read Price as a kind of 'word-world dualist'.

Why is dualism an unsatisfactory metaphysics for a pragmatist? Interesting observations were made here by pragmatism's originator, Charles Peirce. Peirce wrote that dualism, "performs its analysis with an axe, leaving as the ultimate elements, unrelated chunks of being" (Peirce CP, 7.570). Why is that problematic? Because along with any relatedness between the "chunks", one removes the in-principle possibility of any bridging explanations between them. This consequence can be seen clearly in the so-called "Mind-Body Problem", which grew from Cartesian mind-body dualism to bedevil modern philosophy with the mystery of how the allegedly self-contained substance of thought could act on the allegedly self-contained substance of matter.

We see the same in-principle inexplicability in Price. For instance, we've seen him explicitly refuse to explain how i- and e- representations 'gear together' to constitute a language. Yet the question of how in-game answerability and environmental answerability might relate within communication seems prima facie both sensible and important. (The question seems particularly important where the interlocutors are navigating a mutually intelligible world as agents - a feature which pragmatism distinctively highlights as crucial.) Nor does Price attempt to explain how i- and e- representations manage to signify i- and eworlds respectively, and it's not clear how he can. (For instance: how can environmental answerability be understood to "answer to" the e-world, given that Price has thrown away the Semantic Ladder?). Nor does he explain how his i- and e-worlds relate to one another (if they do). And, moreover, he does not see any of this as a problem! We submit that such unconcern is crucially anti-naturalistic. Science only progresses by paying attention to currently unexplained phenomena, and trying to explain them, and a necessary condition for achieving this aim is that one want an explanation. We shall now address the second major metaphysical assumption in Price's views that we wish to highlight.

\section{Price's Nominalism}

We have seen Price argue that the apparent force of the Placement Problem lends weight to various forms of expressivism, which seem better suited than their more metaphysicallyinclined rivals to make sense of things. Similarly, nominalism about universals often appears far more naturalistically kosher than any variety of realism about universals. This is because 
Quine's criterion for ontological commitment (which we have seen Price draw on crucially) seems denuded of any metaphysical commitment to queer entities with queer semantic properties. Rather, the explanation for why it is true to state that something is red lies simply in how the term 'redness', or the predicate 'is red', applies to an object - the truth-conditions of a proposition such as 'The chair is brown', then, are the following: $x$ (some object) is $f$ (some property), because there exists a term which designates $x$ and that ' $\mathrm{f}$ ' applies to $x$ (cf. Devitt 1997, p. 96).

But what if it turned out that nominalism is a key feature of Price's neopragmatism? Claudine Tiercelin notes in her review of Naturalism without Mirrors, "Price has virtually nothing to say ... on realism about universals" (Tiercelin 2013, p. 664). This appears to stem from Price's metaphysical quietism. As we have seen, like Quine and Rorty before him, Price aims to replace the vocabulary of the metaphysician with a putatively more reasonable account of propositional discourse which avoids any metaphysical vocabulary, just as a Good Darwinian provides a convincing explanation for apparently brilliant design solutions in the biological world without mentioning God.

Price and Macarthur will argue that metaphysical quietism does not entail nominalism, since the latter is a specific genus of anti-realist metaphysics - it "retains a metaphysical face: it maintains that literally speaking" (Macarthur and Price 2007, p. 98), there are no universals. In contrast, they urge, metaphysical quietism rejects all metaphysical talk, whether negative or positive assertion (Macarthur and Price 2007, p. 98). However, we shall now argue that metaphysical quietism is self-refuting to the extent that Price must eventually concede that his critique of metaphysics is made on nominalist grounds. One helpful way of explicating our critique of Price here is that he makes the same mistake Rorty made when conceiving of pragmatism as necessarily anti-metaphysics. ${ }^{17}$

Rorty understands metaphysics as the kind of view Hilary Putnam has dubbed 'metaphysical realism', according to which:

the world consists of some fixed totality of mind-independent objects. There is exactly one true and complete description of 'the way the world is'. Truth involves some sort of correspondence relation between words or thought-signs and external things and sets of things (Putnam 1981, p. 49).

This 'God's-eye-view' understanding of metaphysics is summed up by Rorty in a later work: "I use 'metaphysics' as the name of the belief in something non-human which justifies our deep attachments" (Rorty 2001, p. 89). By presenting metaphysics as comprising 'non-human'

\footnotetext{
${ }^{17}$ Cf. (Giladi 2015).
} 
dimensions which transcend our social and cultural practice, Rorty regards it as the great nemesis of pragmatism. ${ }^{18}$ Yet Rorty is committed to a conception of human beings as normative, self-reflecting, discursive agents. But by conceiving of ourselves in this way, he is inevitably engaging in some kind of general inquiry into the nature and structure of reality, as humans are (of course) themselves part of reality. Once again, then, such claims constitute some variety of metaphysics as we have defined it, although they do not involve any appeal to onto-theological categories, nor transcend the bounds of sense. Rather, this nuanced genus of metaphysics is a form of naturalism, according to which we understand what it is to be human in terms of having a particular set of natural capacities. In this way, then Rorty's antimetaphysical pragmatism is self-refuting.

Rorty's mistake can be equally attributed to Price's functional pluralism about meaning. If all worlds are just artefacts of particular discourses, and therefore contingent to human purposes, then Price's global expressivism, and distinction between e- and i- representations, must itself constitute just another discourse. Such a discourse might readily be engaged in alongside further discourse claiming that global expressivism is false, if it serves some human purpose to do so, since there are no external facts to ground the necessity of avoiding contradiction (and the need to avoid contradiction within i-representations appears to be gamespecific, in this view). In response, Price may object that his distinction between in-game answerability and environment answerability is not simply a difference between kinds of discourse, since as noted the notion of 'environment' refers to the world we have in view from natural sciences such as physics. However, if so, Price must recognise that the natural sciences themselves draw on important metaphysical presuppositions. These include: (1) there exists a theory-independent, external world; (2) the world investigated by physics is knowable by humans; (3) the explanations of physics potentially apply across all of reality. Price's picturebook metaphor itself arguably leans heavily on these presuppositions: (1) in positing the 'picture on the right hand side' of the book, (2) in imagining that stickers have an intelligible 'place' in that picture, and (3) the claim (crucial for motivating the Placement Problem) that for every place in the picture there exists a sticker ('phrased' in the language of natural science) to 'fill' it.

Once metaphysics is so understood, it is clearly impossible for the naturalist not have metaphysical commitments in some way or another. This unavoidability of metaphysics is

\footnotetext{
18 "[t]he pragmatist ... does not think of himself as any kind of metaphysician" (Rorty 1982, p. xxviii).
} 
unsurprisingly reflected in the ubiquity of metaphysical concepts in language. ${ }^{19}$ A similar claim is made by Jonathan Lowe:

"[i]n my view, all other forms of inquiry rest upon metaphysical presuppositions - thus making metaphysics unavoidable - so that we should at least endeavour to do metaphysics with our eyes open, rather than allowing it to exercise its influence upon us at the level of uncritical assumption" (Lowe 1998, p. v).

If metaphysical quietism is self-refuting, then Price needs an alternative justification for his critique of metaphysics. What is left? Only, it would appear, Quinean nominalist basic inclinations for understanding reality as a desert landscape. This is exactly the kind of move that Price has strenuously tried to avoid in developing his particular variety of (subject) naturalism as akin to a genus of linguistic anthropology - so that (as noted) the linguistic anthropologist is conceived of as "being silent in one's theoretical voice about whether [semantic] terms refer or have truth-conditions" (Price 2004, p. 80).

While Price insists that the subject naturalist is quiet on these matters, his variety of semantic deflationism in fact appears to make more noise than he is willing to countenance: for, central to Price's subject naturalism is the "idea that the only semantic resources theorists of language need are minimalist ones about which there is little, in general, to say beyond the trivial disquotational schemas ..." (Macarthur 2008, p. 206). Such an idea appears to be very much in the spirit of Quine's nominalist semantic theory sketched above. Under such a theory, one does not need to be committed to the existence of a universal to make the proposition true: one needs only correctly apply a term to a particular. From this formal perspective, there appears to be a significant parallel between Quine and Price: both claim that one needs only minimal semantic resources to make sense of the relevant phenomena, and to insist on only minimal resources is itself symptomatic of nominalist dispositions. Not only that, Price's very subject naturalism arguably presupposes nominalism insofar as it assumes that 'the subject' can be divorced from its broader context of surrounding objects (the experienced world), and studied separately - which assumes the subject to be a discrete individual, rather than, for instance, a node in a web of internal relations.

In conclusion, then, we have shown that Price's neopragmatism makes serious metaphysical assumptions on at least two fronts. We don't blame him for this, metaphysics is unavoidable for a philosopher. But we will now make some suggestions about how, when metaphysics is given its due and properly integrated, pragmatism might look.

\footnotetext{
${ }^{19}$ See (Ellis 2002) and (Lowe 2006).
} 


\section{What is Naturalism? What is Metaphysics?}

We will now briefly discuss the concepts of naturalism and metaphysics, comparing how Price thinks they should be understood within pragmatism with our own views.

\subsection{Naturalism}

We saw that Price defines naturalism as "an ontological doctrine... [that] all there is is the world studied by science", and "an epistemological doctrine...[that] all genuine knowledge is scientific knowledge" (Price, 2004, pp. 73). To us, this ontological doctrine sounds rather empty. Of course, the world that is, is the world that is studied by science - what other world could science study? This definition does not in any way determine the nature of that world, yet is this not something one might hope for from an ontological doctrine? The epistemological doctrine is also quite vague. Reading generously would seem to require understanding it as claiming that the only genuine knowledge is scientific knowledge. (Strictly as stated, the doctrine leaves the possibility open that all genuine knowledge and all non-genuine knowledge might be scientific knowledge.) And what makes knowledge 'scientific'? No guidance is given on this.

We believe that the best understanding of naturalism for pragmatism, with its guiding interest in practice over theory, is neither ontological nor epistemological but methodological. It's worth noting that the scientific knowledge, and the worlds it describes, which are invoked by Price's epistemological and ontological claims respectively, changes significantly over time. Pragmatists have always taught that scientific knowledge, understood as a product of inquiry, is fallible, revisable, and multi-dimensional and moves through various stages and positions in an attempt to achieve rational satisfaction. A more lasting - and thereby arguably more essential - aspect of science is such aspects of its methods that endure while specific scientific beliefs come and go. ${ }^{20}$ Of course, giving an account of such methods which covers the vast variety of sciences currently pursued is a high-level task that must be approached in a very general manner. Nevertheless, we believe that classical pragmatism made useful progress on it. For instance, Peirce taught that one absolutely key aspect is practices of self-correction:

If a man burns to learn and sets himself to comparing his ideas with experimental results in order that he may correct those ideas, every scientific man will recognize him as a brother, no matter how small his knowledge may be (Peirce CP, 1.44).

\footnotetext{
${ }^{20}$ It must be noted that Peirce claims that scientific method also develops to some degree: “...every work of science great enough to be well remembered for a few generations affords some exemplification of the defective state of the art of reasoning of the time when it was written; and each chief step in science has been a lesson in logic.” (Peirce CP, 5.363). But it develops more slowly.
} 
Note how neatly Peirce here separates scientific practice from merely holding scientific knowledge (Price's 'epistemological doctrine'), by observing that one may possess swathes of knowledge of the physical world, but if one is not committed to extending it further, but rather is committed to defending it come what may, then one is not a true scientist. Conversely, one can hold very little scientific knowledge but still be a genuine scientist if one is working diligently to increase one's epistemic 'widow's mite'. This is arguably the key idea behind empiricism, and what made it so attractive as the philosophical representative of the "new sciences' through the 17 th and $18^{\text {th }}$ centuries. For "look to the world of experience!" means, "look beyond your current beliefs!"

Peirce argues (empirically) that the source of these empiricist practices can ultimately only be a certain kind of personal character and motivation. He writes of a class of "men" (people):

...to whom nothing seems great but reason. If force interests them, it is not in its exertion, but in that it has a reason and a law. For men of [this] class, [nature] is a cosmos, so admirable, that to penetrate to its ways seems to them the only thing that makes life worth living... Those are the natural scientific men; and they are the only men that have any real success in scientific research (Peirce CP, 1.43).

Why is character and motivation so important? As Susan Haack has noted, it is because there is such a thing as sham reasoning. This occurs "where it is no longer the reasoning which determines what the conclusion shall be, but it is the conclusion which determines what the reasoning shall be" (CP 1.57). Possibly even worse is fake reasoning, whose practitioners ignore truth altogether and are merely arguing to look clever, get promoted or receive other epistemically extrinsic rewards. Frustratingly, these reasonings are frequently impossible to tell apart from reasonings that lead toward truth by their outward form alone. As Haack also astutely notes:

the intelligence that will help a genuine inquirer figure things out will help a sham or fake reasoner suppress unfavourable evidence more effectively, or devise more impressively obscure formulations (Haack 1996, §7).

That we cannot determine from a form of reasoning alone whether it is truth-directed is in fact exactly what we should expect from a genuine empiricism, or knowledge by experience. But the genuine lover of truth will not be satisfied with sham or fake reasoning, by definition, and Peirce claims that there is no epistemic tool, technique, logic or premise that can inoculate us against it, other than this ardent desire. Many pragmatists argue that we need to understand these matters in order to understand scientific practice, and thus, naturalism. 


\section{ii) Metaphysics}

We saw that for Price metaphysics consists in the holding of ontological commitments understood solely as specific objects in the world which 'hang off' our true sentences and (to use his picture-book metaphor) have the same 'shape', somehow. Metaphysics can involve much more than this, and has done so in a rich tradition stretching back 2000 years. We think it a pity that Price did not consider a few alternative conceptions of the discipline before dismissing it so wholeheartedly. Here are just a few examples:

- Metaphysics was defined by Aristotle as the study of being qua being, meaning what can be asserted about anything that exists just because of its existence and not because of any special qualities it has. Price might have adapted this conception to his minimalistic subject naturalism in interesting ways. For instance, he might have focussed on the subject as a 'pure I', constituted by existence rather than essence. This would have delivered to his pragmatism an existentialist twist which could have been most intriguing to develop.

- Jonathan Lowe defined metaphysics as a series of general enquiries into the fundamental structure of reality as a whole (Lowe 2002, pp. 2-3). Similarly, Adrian Moore (following Wilfrid Sellars) wrote, "Metaphysics is the most general attempt to make sense of things" (Moore 2012, p. 1). We have already urged that such a general enquiry is also a goal of naturalism. Natural scientists not only do a great deal of detailed fact-finding, but also develop theories of the world's overall structure. Price qua naturalist might have made good use of this scientific conception of metaphysics.

- Paul Forster writes: "The task of the metaphysician ... is to think through the implications of the theory of inquiry for our general concept of reality" (Forster 2011, p. 176). In this spirit he draws metaphysical implications from his own theory of inquiry, such as a particular (semiotically inflected) form of realism about universals. This inquiry-led approach to metaphysics is particularly pragmatist, and since human beings would appear to be the inquiring species, Price's subject naturalism with its focus on human linguistic practices might have served as a wonderful platform for this kind of investigation.

Even within analytic philosophy there are more conceptions of metaphysics on the table than Price acknowledges, as Paul Horwich has noted. ${ }^{21}$ For instance, an influential new movement critiques Quine's overwhelming focus on "existence questions", the answers to which are

\footnotetext{
${ }^{21}$ See (Horwich, 2013, pp. 113-121)
} 
"extracted from our best theory", suggesting that more important are questions concerning what grounds what, what is "ontologically primary". When it comes to philosophically contested entities such as numbers, Jonathan Schaffer notes, "the philosophical question is not whether such things exist but how they do" (Schaffer 2009, p. 352)22 - do they supervene on the physical world, or not? Once again, such 'grounding' questions could be very interesting naturalist questions for Price to explore. For instance, are i-representations grounded in human practices (as Price's linguistic functionalism would seem to require), and if so, in what way? Are irepresentations grounded in e-representations, given that human language is just one among many natural phenomena, and if so, in what way?

\section{Conclusion}

Metaphysics is far from a worthless intellectual enterprise, but has an important role in finding our place in the Universe. (We might call this our own humble, human "Placement Problem".) By pursuing a sufficiently general inquiry into the nature and structure of reality, metaphysics seeks to render a natural order that is arguably non-anthropocentric rationally intelligible to human mindedness. It is helpful at this point to turn to Hegel, who offers such an explanation of metaphysics' significance:

It is true that Newton expressly warned physics to beware of metaphysics; but ... let it be said that he did not conduct himself in accordance with this warning at all. Only the animals are true blue physicists by this standard, since they do not think: whereas humans, in contrast, are thinking beings, and born metaphysicians. All that matters here is whether the metaphysics that is employed is of the right kind: and specifically whether...we hold on to one-sided thought-determinations fixed by the understanding, so that they form the basis of our theoretical and of our practical action (Hegel 1991, $\S 98 \mathrm{Z}, 156)$.

For Hegel, the principal advantage of drawing a distinction between the mere understanding alluded to above, and his broader category of reason, is that we can avoid various problematic dualisms which are the inevitable consequence of purely analytical methods of reflection, which force us into contradictions and aporias. Reason provides inquirers with the means to avoid these pitfalls by thinking dialectically - drawing distinctions yet at the same time establishing interconnectedness to a whole. A metaphysics which conflates reason with understanding, will therefore not be a maximally useful metaphysics, insofar as it results in a one-sided conception of thought and a purely mechanistic conception of philosophic

\footnotetext{
${ }^{22}$ See also (Schaffer 2012).
} 
explanation. In these ways, then, Hegel offers us a recognisably pragmatist conception of metaphysics.

That metaphysics seems to keep returning from attempts to abolish it, and is experiencing a powerful resurgence in contemporary analytic philosophy may signal just how important the discipline is to humans. Metaphysics at its best seems to reveal what is crucial to inquiry namely "radically new concepts by which to live" (Moore 2012, p. 20). As such, the effort to make sense of things is not just an exercise in representing states of affairs, it is also an exercise in finding ways for human beings to realise themselves through practices of understanding the nature of reality and our place in it. And aren't such practices a goal to which pragmatists have always aspired? Price's oeuvre also presents us with a picture of how we fit in the Universe, but, we suggest - not a happy one. For instance, we have seen that the 'priority' he gives to subject naturalism precisely assumes that the human subject can be divorced from its broader context (a directly experienced world), and studied separately. The ensuing dualism and nominalism invoke the 'natural' world as a desert landscape devoid of nonanthropocentric intelligibility, and conceive of inquiry as involving a sparse conception of discourse which seeks to limit the kinds of conversation one can have. If it is true, as we have argued, that metaphysics consists in a general inquiry into the nature and structure of reality, to try to block it seems a puzzling exercise in epistemic self-harm. We close with warnings from Putnam:

In every philosopher there is a part that cries, "This enterprise [of metaphysics] is vain frivolous, crazy-we must say "Stop!", and a part that cries, "This enterprise is simply reflection at the most general and abstract level; to put a stop to it would be a crime against reason. (Putnam 1988, p. 457)

and Peirce:

Find a scientific man who proposes to get along without any metaphysics... and you have found one whose doctrines are thoroughly vitiated by the crude and uncriticized metaphysics with which they are packed....Every man of us has a metaphysics, and has to have one; and it will influence his life greatly. Far better, then, that that metaphysics should be criticized and not be allowed to run loose. (Peirce CP, 1.129)

\section{REFERENCES}

Armstrong, D. M. (1982). A Theory of Universals. Vol. I Nominalism and Realism; Vol. II Universals and Scientific Realism. Cambridge: Cambridge University Press. Blackburn, S. (1993). Essays in Quasi-Realism. Oxford: Oxford University Press. 
Boghossian, P. A. (1990). “The Status of Content.” The Philosophical Review 99 (2), 157-184. Brandom, R. (1994). Making It Explicit: Reasoning, Representing, and Discursive Commitment. Cambridge MA.: Harvard University Press.

Brandom, R. (2000a). Articulating Reasons: An Introduction to Inferentialism. Cambridge, Mass.: Harvard University Press.

Brandom, R. (Ed). (2000b) Rorty and His Critics. Oxford and Cambridge MA: Blackwell.

Crane, T., and Mellor, D.H. (1990). "There is no Question of Physicalism.” Mind 99 (394), 185-206.

Forster, P. (2011). Peirce and the Threat of Nominalism. Cambridge: Cambridge University Press.

Giladi, P. (2015). “A Critique of Rorty's Conception of Pragmatism” European Journal of Pragmatism and American Philosophy 7 (2), 168-185.

Giladi, P. (2014a). "Ostrich Nominalism and Peacock Realism: A Hegelian Critique of Quine." International Journal of Philosophical Studies 22 (5), 734-751.

Giladi, P. (2014b). "Liberal Naturalism: The Curious Case of Hegel." International Journal of Philosophical Studies 22 (2), 248-270.

Giladi, P. (2015). 'A Critique of Rorty's Conception of Pragmatism'. European Journal of Pragmatism and American Philosophy 7, 168-185.

Jackson, F. (1998). From Metaphysics to Ethics: A Defence of Conceptual Analysis. Oxford: Oxford University Press.

Jackson, F. (1997). "Naturalism and the Fate of the M-Worlds II", Proceedings of the Aristotelian Society, Supp. Vol. 71, 269-82.

Haack, S. (2004). "Pragmatism, Old and New." Contemporary Pragmatism 1 (1), 3-41.

Haack, S. (1996). "Concern for Truth: What it Means, Why it Matters.” P. R. Gross, N. Levitt, and M. W. Lewis (Eds), The Flight from Science and Reason. New York: New York Academy of Sciences, 57-63.

Hegel, G. W. F. (1991). The Encyclopaedia Logic. T. F. Geraets, W. A. Suchting, and H. S. Harris (trans.) Indianapolis/Cambridge: Hackett Publishing Company, Inc.

Hempel, C. G. (1976). "Empiricist Criteria of Cognitive Significance: Problems and Changes," S. Harding (Ed.) Can Theories be Refuted? Essays on the Duhem-Quine Thesis. Dordrecht: Springer, 65-85.

Heney, D. (2015). "Reality as Necessary Friction”, Journal of Philosophy 112 (9), 504-514.

Hoopes. J. (1998). Community Denied: The Wrong Turn of Pragmatic Liberalism. New York: Cornell University Press.

Koopman, C. (2007). "Language is a Form of Experience: Reconciling Classical Pragmatism and Neopragmatism." Transactions of the Charles S. Peirce Society 43 (4), 694-727.

Ladyman, J. and Ross, D. (with Spurrett, D. and Collier, J.). (2007). Everything Must Go: Metaphysics Naturalized. Oxford: Clarendon Press.

Legg, C. (2014). “Charles Peirce's Limit Concept of Truth.” Philosophical Compass 9 (3), 204-13.

Legg, C. (2010). "Huw Price”, N. Trakakis (Ed) Companion to Philosophy in Australia and New Zealand. Melbourne: Monash University Press, 474-477.

Legg, C. (2005). “The Meaning of Meaning-Fallibilism”, Axiomathes, 15 (2), (2005) 293-318 
Legg, C. (2001). "Predication and the Problem of Universals." Philosophical Papers 30 (2), 117-143.

Levine, S. (2012). "Brandom's Pragmatism." Transactions of the Charles S. Peirce Society: A Quarterly Journal in American Philosophy 48 (2), 125-140.

Lowe, E. J. (2002). A Survey of Metaphysics. Oxford: Oxford University Press.

Macarthur, D. and Price, H. (2007). "Pragmatism, Quasi-realism and the Global Challenge." In Cheryl Misak (Ed). (2007), 91-121

Misak, C. (Ed.). (2007). The New Pragmatists. Oxford: Oxford University Press.

Misak, C. (2013). The American Pragmatists. Oxford: Oxford University Press.

Moore, A.W. (2012). The Evolution of Modern Metaphysics: Making Sense of Things. Cambridge: Cambridge University Press.

Price, H. (with Blackburn, S., Brandom, R., Horwich, P., Williams, M.). (2013). Expressivism, Pragmatism and Representationalism. Cambridge: Cambridge University Press.

Price, H. (2011). Naturalism without Mirrors. Oxford: Oxford University Press.

Price, H. (2010). “One Cheer for Representationalism?” R. Auxier (Ed), The Philosophy of Richard Rorty: Library of Living Philosophers XXXII Chicago: Open Court.

Price, H. (2004). "Naturalism without Representationalism", in De Caro and Macarthur (2004), $71-88$.

Price, H. (2003). “Truth as Convenient Friction.” Journal of Philosophy C, 4, 167-90.

Price, H. (1998). "Two Paths to Pragmatism II.” European Review of Philosophy 3,109-47.

Price, H. (1997a). "Naturalism and the Fate of the M-Worlds." Proceedings of the Aristotelian Society Supp. Vol. 71, 247-67.

Price, H. (1997b). "Carnap, Quine and the Fate of Metaphysics." Electronic Journal of Analytic Philosophy, 5(1) https://ejap.louisiana.edu/EJAP/1997.spring/price976.html (Downloaded 29 March, 2018).

Price, H. (1988). Facts and the Function of Truth. Oxford: Blackwell.

Putnam, H. (1988). “After Metaphysics, What?" D. Henrich and R-P Horstmann (Eds.), Metaphysik nach Kant, 457-66.

Redding, P. (2010). Analytic Philosophy and the Return of Hegelian Thought. Cambridge: Cambridge University Press.

Rorty, R. (1995). "Is Truth a Goal of Inquiry? Davidson vs. Wright." The Philosophical Quarterly 45 (180), 281-300.

Rorty, R. (1982). Consequences of Pragmatism. Minneapolis: University of Minnesota Press.

Rorty, R. (1980). Philosophy and the Mirror of Nature. Princeton: Princeton University Press.

Rorty, R. (1978) "Philosophy as a kind of writing: An essay on Derrida." New Literary History 10 (1), 141-160.

Schaffer, J. (2009). “On What Grounds What.” In David Manley, David J. Chalmers \& Ryan Wasserman (eds.), Metametaphysics: New Essays on the Foundations of Ontology. Oxford: Oxford University Press, pp. 347-383.

Schaffer, J. (2012). "Grounding, Transitivity, and Contrastivity." In Fabrice Correia, Benjamin Schneider (eds.), Metaphysical Grounding: Understanding the Structure of Reality. Cambridge: Cambridge University Press, pp. 122-138. 
Tiercelin, C. (2013). Essay Review: "No Pragmatism without Realism - Huw Price: Naturalism without Mirrors." Metascience 22, 659-665. 